\title{
Structure formation of construction materials modified with natural and man-made nanoadditives
}

\author{
Irina Polyanskikh ${ }^{1}$, Grigorij Yakovlev ${ }^{2}$, Grigorij Pervushin ${ }^{3}$, Alexandr Gumeniuk ${ }^{4}$, \\ Anastasija Gordina $^{5}$, Anastasija Ignateva ${ }^{6}$
}

Construction Materials, Mechanization and Geo-Engineering, Shumilov Institute of Construction and Architecture, Kalashnikov Izhevsk State Technical University, 426069, Studencheskaya 48, bld. 2, Izhevsk, Russian Federation

\section{E-mail: 'irina_maeva@mail.ru (correspondingauthor)}

\begin{abstract}
The article focuses on the study of influence of natural and man-made nanoformations (chrysotile fibers, carbon black, and graphite) on the formation of the structure of the material based on a hydraulic binder. The data on the positive effect of the optimal amount of modifying dispersions on the physical and technical properties of the samples were obtained. On average, the increase in compressive and bending strength, when using the considered additives, is from 10 to $40 \%$. The results of the study of the microstructure and IR spectra of the check and modified compositions show that adding natural and man-made nanosystems provides optimal conditions for the formation of strong, dense new formations in the cement matrix. In general, the data obtained prove the effectiveness of their use in comparison with synthesized carbon nanosystems.
\end{abstract}

Keywords: natural nanoddditives, man-made nanoadditives, structure, dispersions, chrysotile fiber, soot dispersion, lamellar carbon nano-formations.

\section{Introduction}

Over the past decade, the number of theoretical and experimental researches devoted to modification of building composites with dispersed additives to increase certain physical and technical parameters has increased several times (Kharitonov, Korobkova, \& Smirnova, 2015; Reches, 2018). Most of empirical studies are devoted to the selection of effective nanodispersed additives and the development of technological methods for the functionalization of the surface of nanosystems (Muhd Norhasri, Hamidah, \& Mohd Fadzil, 2017; Liu, Yu, Liu, Jin, \& Liu, 2018).

Stimulating the uniform distribution of nanoscale additives in the volume of the composition is achieved in various ways, including pretreatment of nanosystems with strong chemicals and/or physical impact on dispersions, etc. (Cwirzen, Habermehl-Chirzen, \& Penttala, 2008; Liu, Han, Li, \& Yan, 2018; Hongyu, Binmeng, Bo, Shengwen, \& Zongjin, 2017). A much less number of papers are devoted to the theoretical aspects of nanomodification and mechanisms accompanying the formation of the structure and properties of materials when adding nanodispersed additives.

The analysis of studies in the field of nanomodification showed that most of them are devoted to the modification of hydration hardening binders (Voitovich, Cherevatova, Zhernovsky, Fisher, \& Sobolev, 2014; Alafogianni, Dassios, Tsakiroglou, Matikas, \& Barkoula, 2019), polymeric and organic materials (Santagata, Baglieri, Tsantilis, \& Chiappinelli, 2013), and to a lesser extent ceramic materials (Dillon et al., 2015). At the same time, synthesized carbon-based products, including various types of fullerenes, nanotubes, and graphenes, are suggested as an active modifying component (Korayem, Tourani, Zakertabrizi, Sabziparvar, \& Duan, 2017; Hawreen $\&$ Bogas, 2019). There are also some researches on modification by means of titanium nanodioxide, nanosilica, nanocellulose, nanodispersed forms of hydrosilicates, etc. (Pinto, Bernardo, Amaro, \& Lopes, 2015; Singh, Bhattacharyya, Shah, Mishra, \& Sharma, 2016).

The high cost of synthesized nanoproducts explains the relevance of search for alternative low-cost additives for modification of composite materials.

The choice of an effective nanomodifying component is determined by such parameters as cost, technological characteristics of modification, and the nature of the modifier. These parameters were taken into account when selecting alternative nanomodifying additives, while evaluating the possible mechanism of their influence, their

(C) 2019 Authors. Published by VGTU Press. This is an open-access article distributed under the terms of the Creative Commons Attribution (http://creativecommons.org/licenses/by/4.0/) License, which permits unrestricted use, distribution, and reproduction in any medium, provided the original author and source are credited. 
chemical affinity with the binding matrix, the value of the specific surface, and the geometric parameters of the active component.

For example, natural chrysotile nanofibers were used as an alternative to multi-walled carbon nanotubes, and carbon black (soot) and graphite were used as man-made graphene-like modifying components. The suggested analogues have a sufficiently high specific surface area and geometrical parameters that are not inferior to the synthesized components, while their cost is several times lower compared to carbon nanosystems.

\section{Experimental program}

The experiments used water dispersions of nanoscale systems with surface-active substances that perform the plasticizing and dispersing role. The dispersion of modifying components was achieved using a VTG- $2.2 \mathrm{~kW}$ vortex heat generator (Yakovlev et al., 2011), providing cavitation effect on the prepared suspension. The quality of the suspensions obtained and the average particle diameter of the additives were evaluated using a SALD-7500nano laser analyzer.

The study used a hydraulic binder of Portland cement as a matrix for determining the degree of influence on the structure and properties of the alternative nanomodifiers.

The required amount of nano-modifiers to add was determined using a complex of physical and technical parameters, including water tightness and compressive and bending strength. These were used in order to determine the optimal compositions.

As an alternative to synthesized carbon nanotubes, chrysotile nanofibers were used (chemical composition $3 \mathrm{MgO} \cdot 2 \mathrm{SiO}_{2} \cdot 2 \mathrm{H}_{2} \mathrm{O}$ ), producibility of which is provided by the structure of fibers (Figure 1a) and the dispersion mode (Figure 1b). Their effectiveness is ensured by high adsorption capacity, chemical affinity and, consequently, the formation of strong topochemical bonds with mineral binders. This study used a mineral from the serpentine group, which, unlike the minerals of the amphibole group, does not adversely affect human life and health (Asbestos..., 2012; Peredelsky \& Prikhodchenko, 2003).

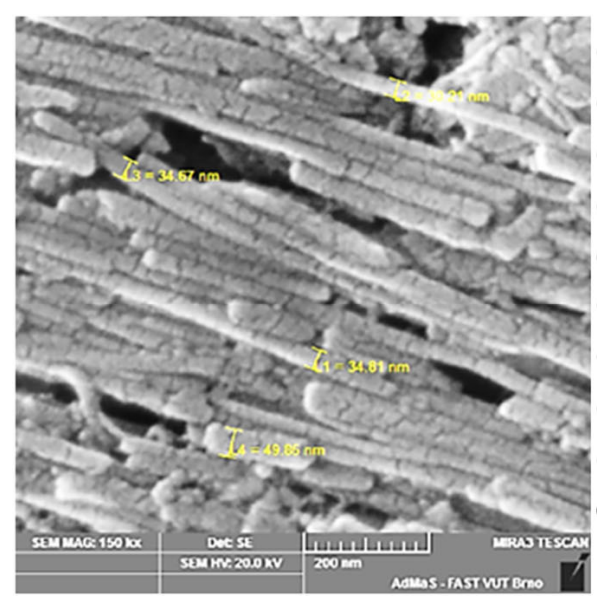

a)

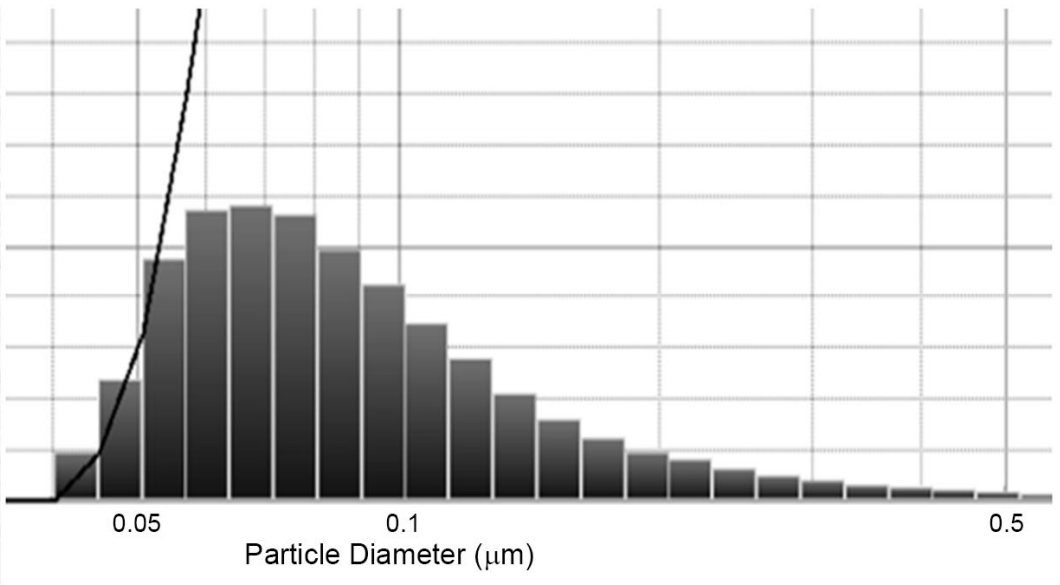

b)

Figure 1. Chrysotile fibers coated with surfactant at a 150,000-fold magnification in nanosuspension - (a), distribution of fibers in nanosuspension - (b)

\section{Experimental process}

Physical and technical studies of the modified cement-based compositions with dispersions of chrysotile nanofibers showed that the maximum increase in strength was achieved after adding the additive in the amount of $0.1 \%$, while an increase in compressive strength, compared to the check sample, was $78.5 \%$, and an increase in bending strength up to $50 \%$.

When the cement matrix is modified with a suspension of chrysotile nanofibers, in comparison with the check sample (Figure 2a), the process of structure formation changes, which leads to the formation of a denser structure with lamellar new formations in combination with cubic and octahedral crystals. 


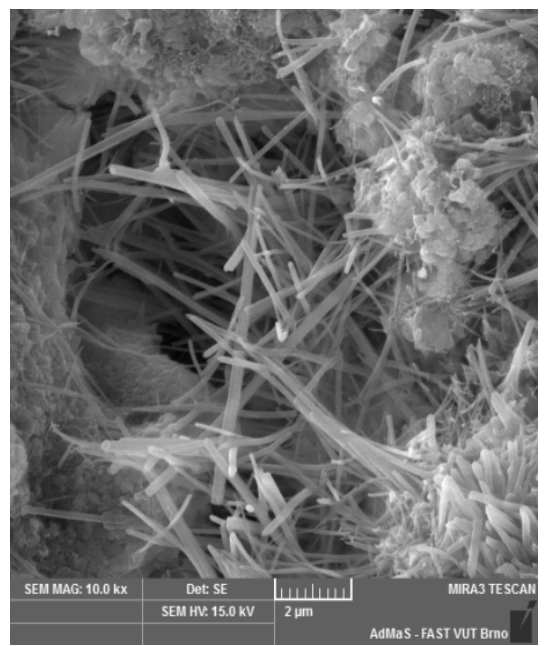

a)

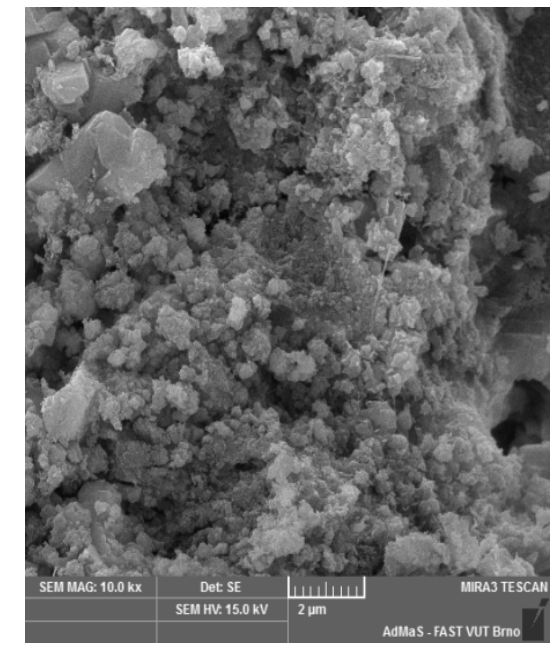

b)

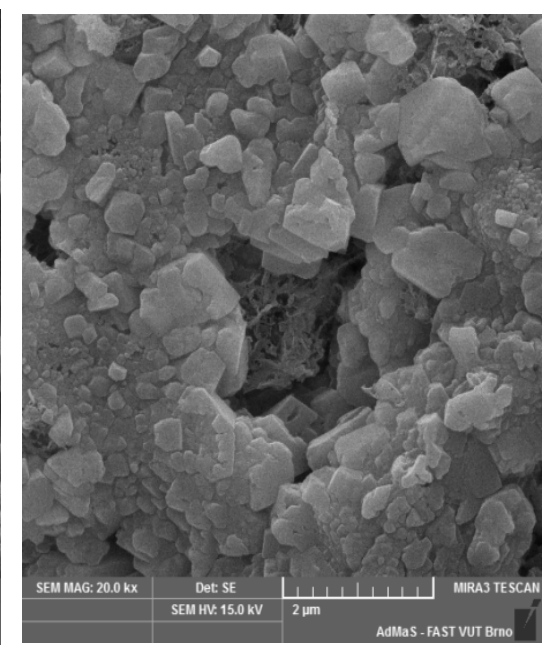

c)

Figure 2. Microstructure of the cement matrix: a) - the check sample; the sample modified with suspension of chrysotile nanofibers; b) - at a 10,000-fold magnification; c) - at a 20,000-fold magnification

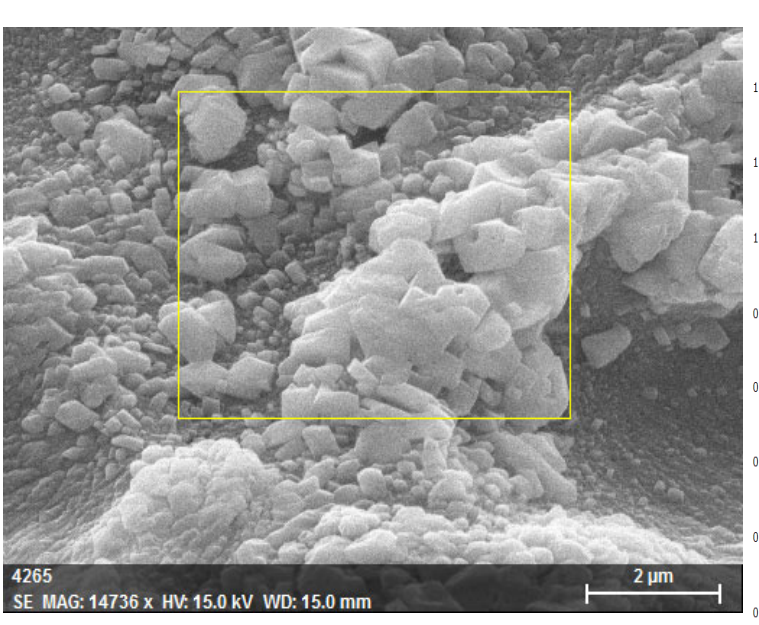

a)

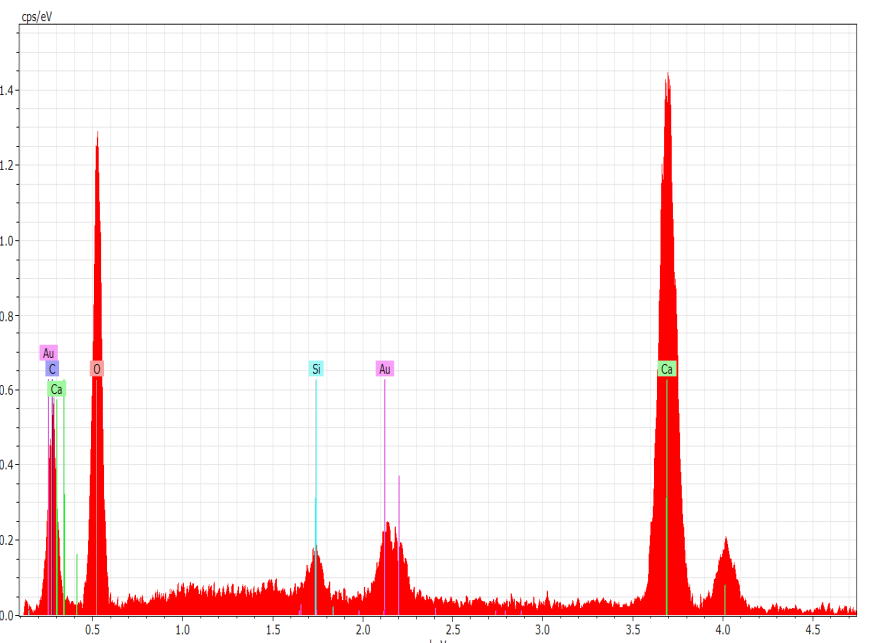

b)

Figure 3. Microstructure of the cement matrix modified with a suspension of chrysotile nanofibers - a), X-ray microanalysis spectrum - b)

X-ray microanalysis of the cement matrix surface modified with a suspension of chrysotile nanofibers confirmed the presence of low basicity hydrosilicates and carbonized calcium hydroxide of cubic structure (Figure 3).

The analysis of the IR spectra (Figure 4) shows that when a suspension of chrysotile fibers (Figure 4 b) is added to the cement-based composition, the intensity of the absorption line corresponding to the group $-\mathrm{Si}-\mathrm{O}-\mathrm{Si}-(\mathrm{v}=$ $1000-900 \mathrm{~cm}^{-1}$ and $692.44 \mathrm{~cm}^{-1}$ ) changes with a shift of the absorption lines to the low-frequency region, which suggests a change in the basicity of calcium hydrosilicates. The peak shift towards low-base silicates is associated with an increase in the material strength (Kaushansky, 1977; Gorshkov, Saveliev, \& Abakumov, 1994). A decrease in the intensity of the absorption lines corresponding to the group $\mathrm{CO}_{2}\left(v=1419\right.$ and $\left.870 \mathrm{~cm}^{-1}\right)$ is found in the cement matrix modified with chrysotile nanofibers, which indicates a decrease in the degree of carbonation of the surface of calcium hydroxide due to an increase in the density of its structure.

Thus, adding a suspension of chrysotile nanofibers was experimentally confirmed to allow creating favorable conditions for the formation of more stable new formations contributing to the optimization of the structure and material strengthening.

At present, graphene oxide is also used as a structure-forming component for hydration hardening binders (Chuah, Pan, Sanjayan, Wang, \& Duan, 2014; Lin, Wei, \& Hu, 2016), which leads to an increase in the strength properties of composites based on hydraulic binders (Fedorova, Aleksandrov, Skryabin, \& Baishev, 2018; Shang, Zhang, Yang, Liu, \& Liu, 2015) and air hardening binders (Kondakov \& Mikhaleva, 2014; Du, H., Gao \& Pang, 2016). 


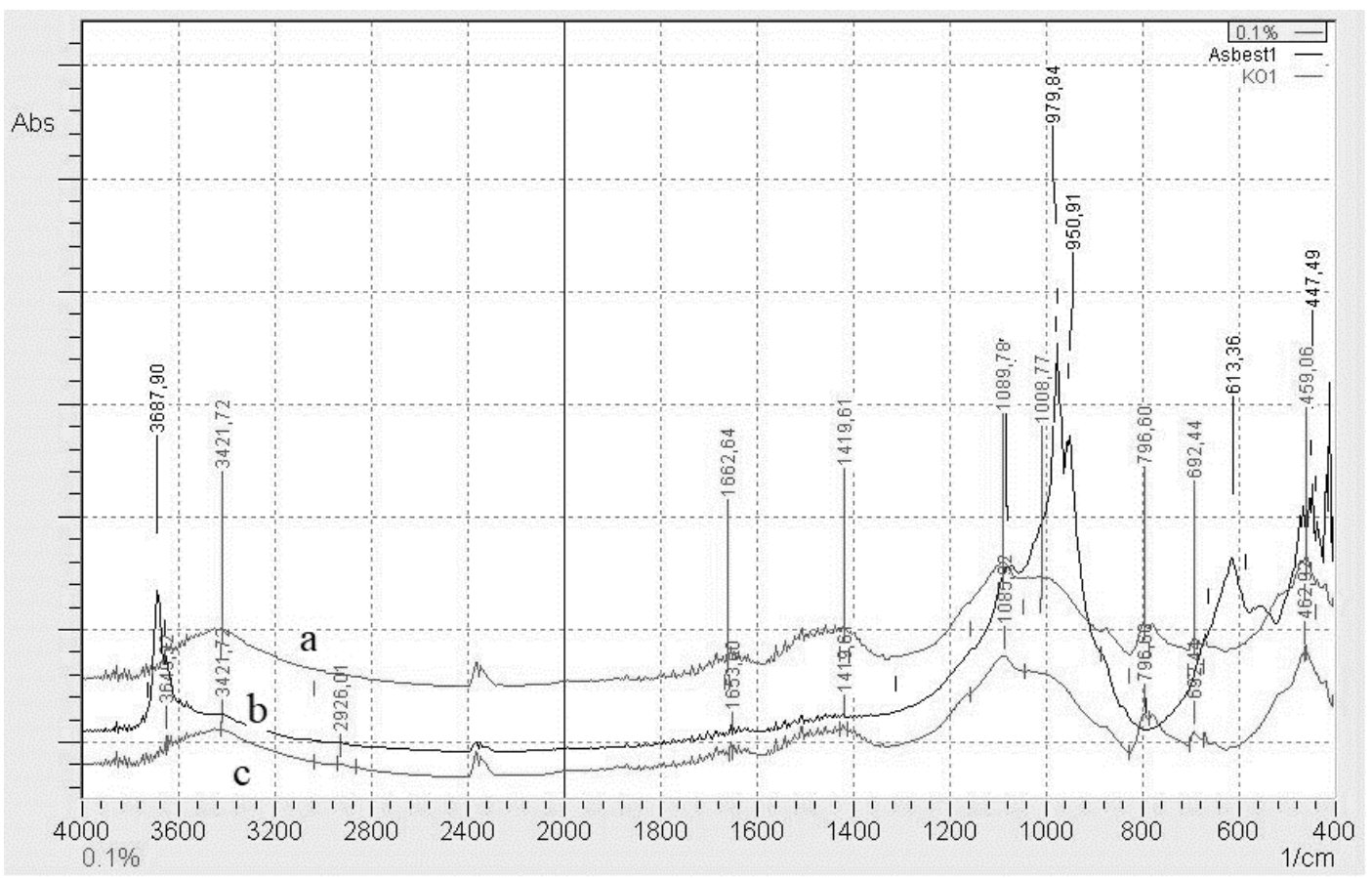

Figure 4. IR spectra: a) - the cement matrix of the check sample; b) - the sample modified with a suspension of chrysotile nanofibers; $c$ ) - suspension with chrysotile nanofibers

After analyzing the studies on adding ultrafine soot (Sarajkina et al., 2015) to the composition of cement-based composite materials (Flores Medina, Barbero-Barrera, \& Bustamante, 2016; Flores Medina \& Barbero-Barrera, 2017), it was suggested that dispersions with an active component in the form of nanosized soot can manifest a structuring effect similar to the effect of modification with additives based on synthesized graphene.

Carbon black was used in the study as an alternative component of the modifying additive (Figure 5), whose structure is characterized by the presence of amorphous carbon and crystalline graphite (the interplanar distance between graphite-like layers is $0.35-0.365 \mathrm{~nm}$ ), the particle size is $13-120 \mathrm{~nm}$.

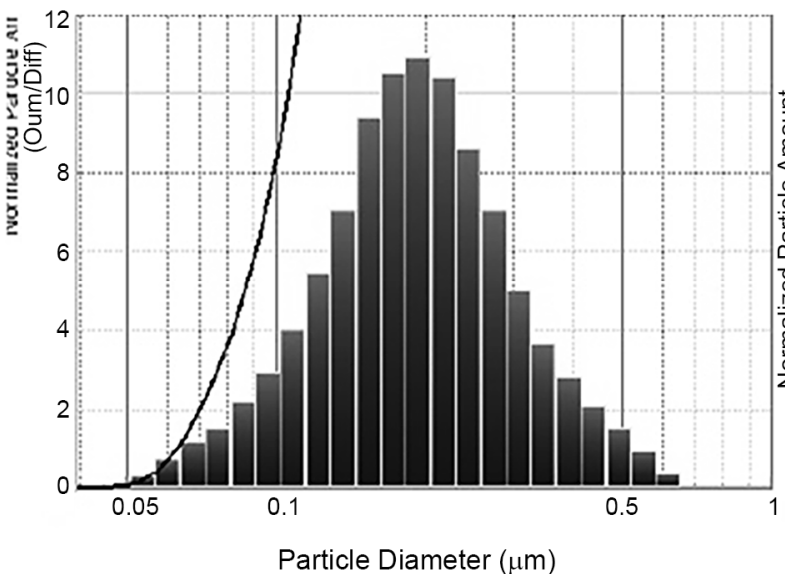

a)

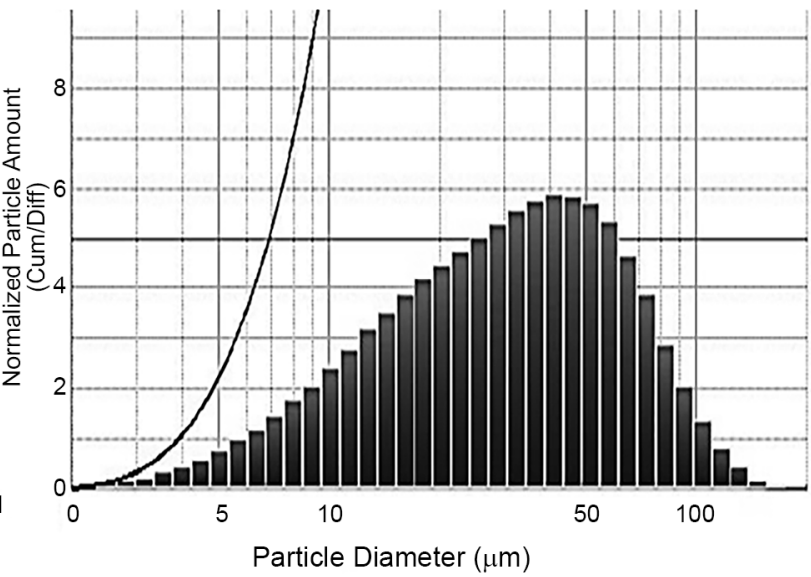

b)

Figure 5. Dispersion analysis of soot: a) - freshly prepared dispersion b) - at the age of 3 years

The conducted studies of physical and technical properties of cement-based samples modified with dispersion of freshly prepared soot showed that the optimal amount of the additive is $0.005 \%$ by weight of the binder. The modifier provides an increase of compressive strength of $19.5 \%$ and bending strength of $50.25 \%$, respectively.

To study the processes that occur when soot is added to the dispersion mixture, the microstructure of the modified samples was analyzed. The result is shown in Figure 6. 


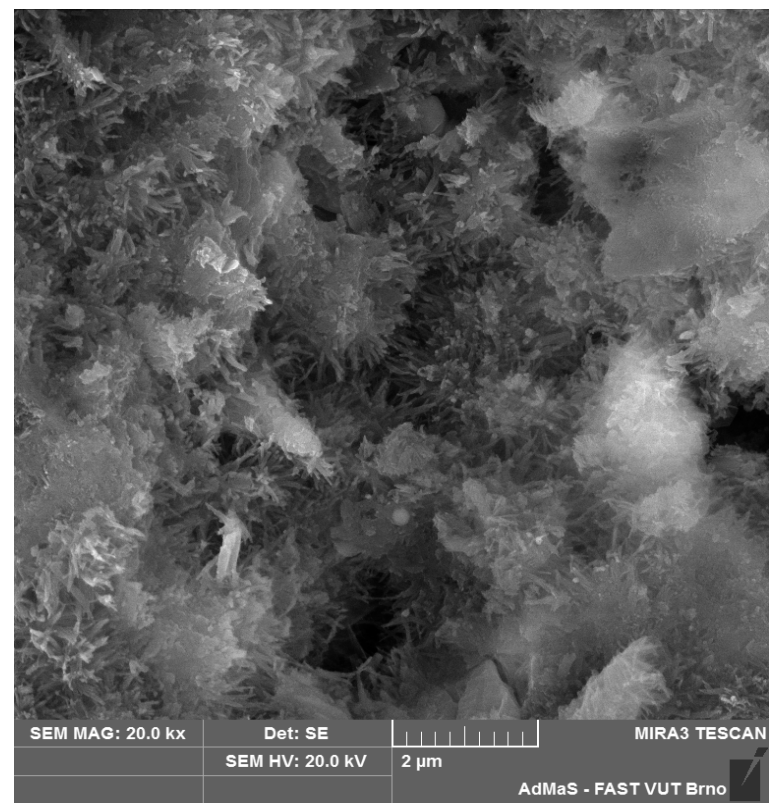

a)

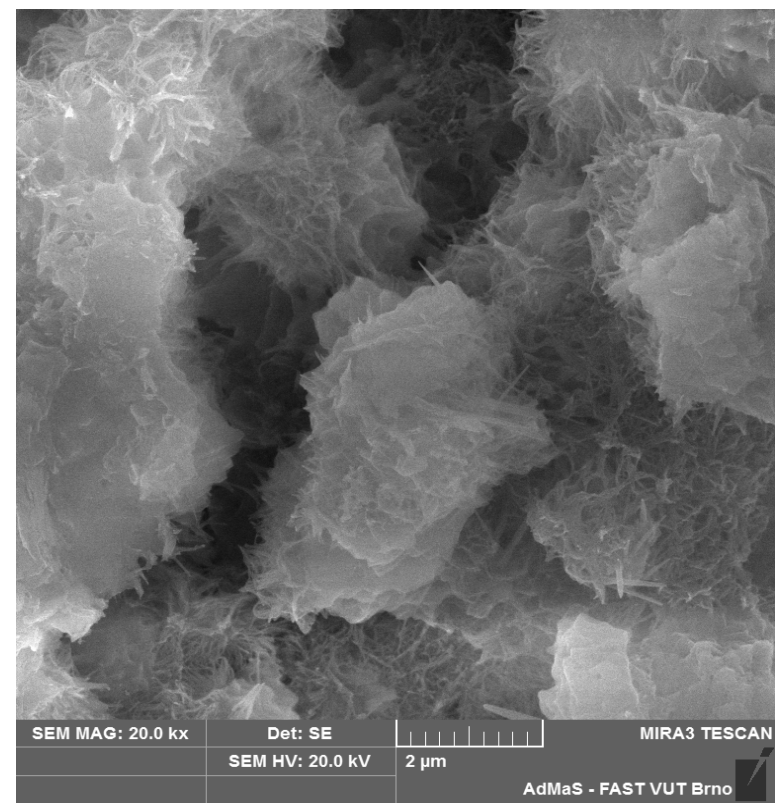

b)

Figure 6. Microstructure of the cement-based composition modified with soot dispersion at a 20,000-fold magnification: a) - the check sample b) - the sample modified with a freshly prepared soot dispersion

As the presented figures show, the check sample has a slightly connected, porous structure represented with new formations in the form of calcium hydroxide and calcium hydrosilicates. An optimal sample modified with a freshly prepared soot dispersion, has a large number of amorphous formations of lamellar structure and its pore space is filled with hydrosilicates.

IR spectral analysis of the cement matrix showed a significant difference in the spectra of the samples (Figure 7).

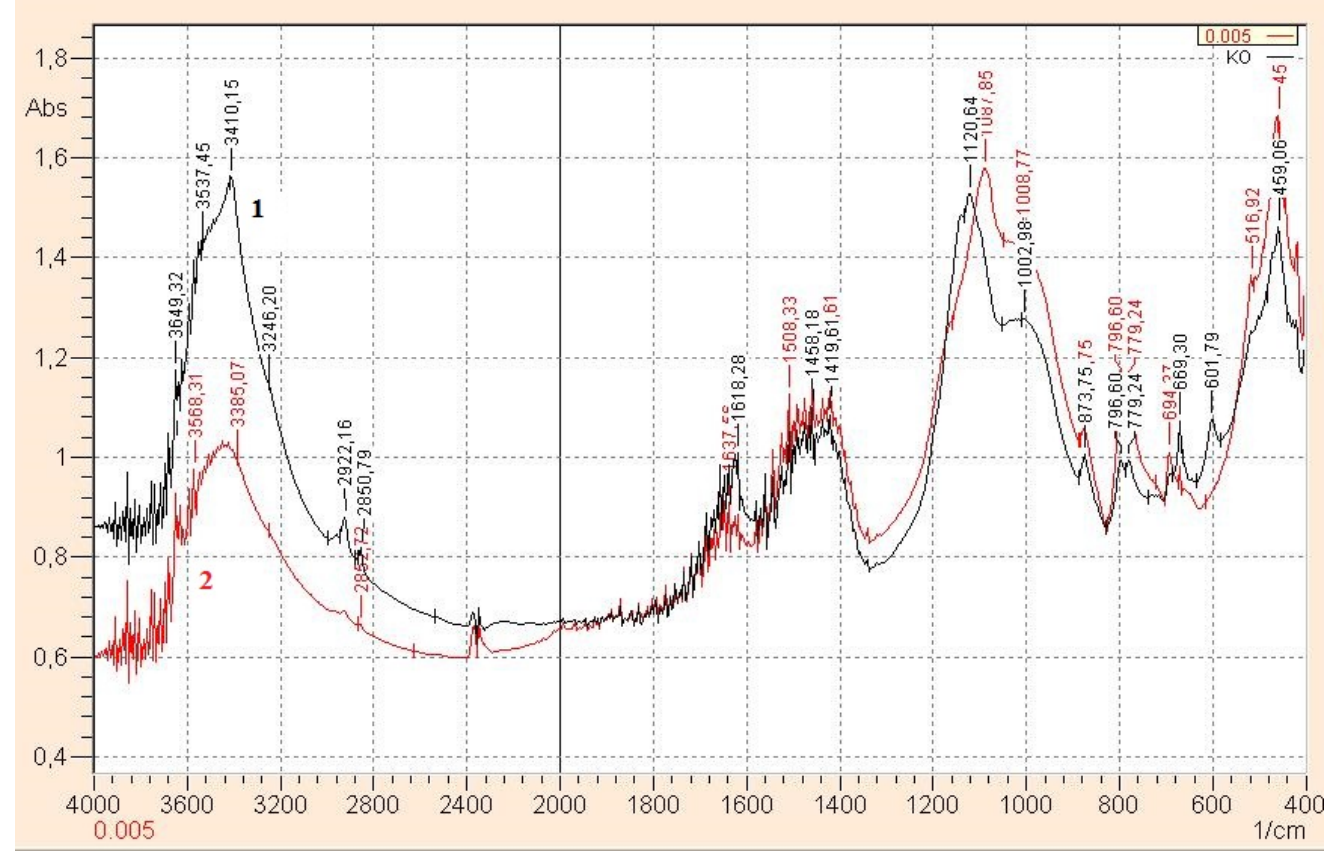

Figure 7. IR spectra of cement-based samples: (1) - the check sample and (2) - modified with a freshly prepared soot dispersion, in the amount of $0.02 \%$ by weight of the binder

In the spectrum of the optimal sample, the intensity of the absorption line decreases in the area $1008.7 \mathrm{~cm}^{-1}$ and there is a shift of absorption lines corresponding to calcium hydrosilicates from 1120.64 to $1087.85 \mathrm{~cm}^{-1}$. In this case, it suggests a change in the basicity of calcium hydrosilicates, which implies an increase in the strength of the 
cement matrix. The changes of absorption lines with values 3385.07 and $1637.58 \mathrm{~cm}^{-1}$, corresponding to bound water, confirm the decrease in the amount of free calcium hydroxide due to its binding into calcium hydrosilicates.

Thus, comparing the obtained data, we can speak about the structuring of the cement-based material with soot dispersions, which leads to compaction of contact layers between new formations, as well as to intensification of the process of cement hydration with the formation of calcium hydrosilicates of lower basicity. At the same time, these effects in terms of the degree of influence on the structure of the cement matrix are comparable to the effect of dispersions of carbon nanotubes, and the cost of soot dispersions is several times lower, respectively.

Therefore, the effectiveness of using aqueous soot-based dispersions as a modifying additive has been proven. It is manifested in the improved physical and technical characteristics of cement-based materials due to the optimal conditions for the directed structure formation.

\section{Analysis of results}

In order to confirm the suggested hypothesis about the directed structuring with graphene-like systems, technical graphite dispersions (substandard graphite electrodes used for electric arc steel smelting in metallurgical industry) were used as an active component with a nanometer range. The study and analysis of the microstructure of the synthesized and man-made graphene-like formations showed that the man-made systems have a similar morphology of extended plates, with a thickness from 0.05 to $0.01 \mu \mathrm{m}$ (Figure 8).

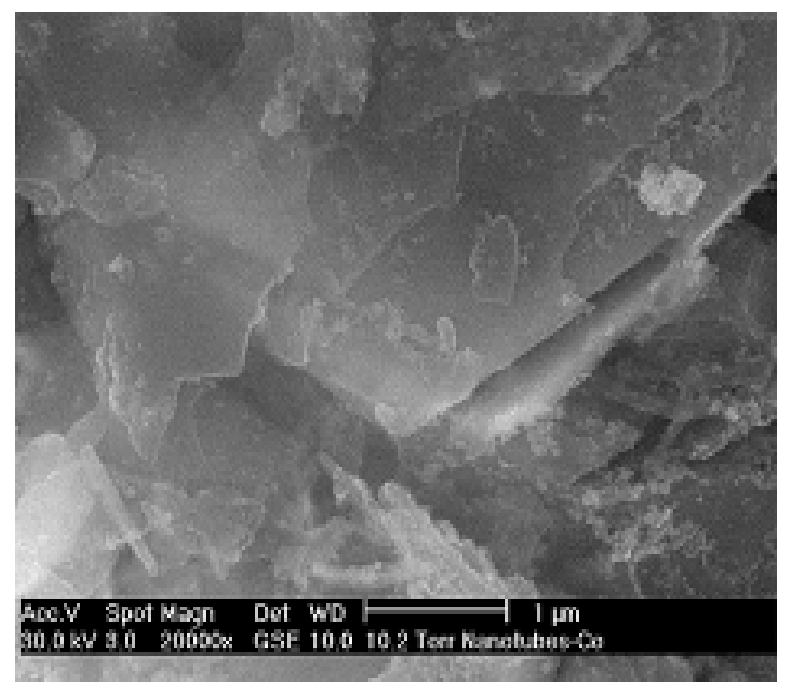

a)

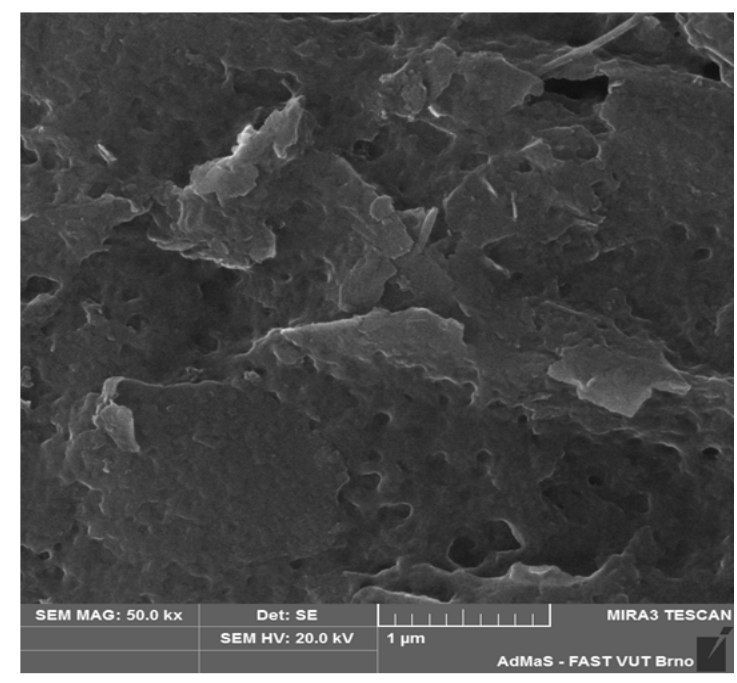

b)

Figure 8. Microstructure of film nanoformations: synthesized lamellar carbon nano-formations with inclusions of copper-containing nanoparticles - (a) (Trineeva, 2009), graphite lamellar structure - (b)

The previous studies proved the optimal amount of synthesized film carbon nanoformations for modifying a fluoro-anhydrite binder to be $0.002 \%$ by weight of the binder. Adding the determined amount of the modifier leads to an increase in the physical and technical characteristics of the material by $20-30 \%$, depending on the synthesis conditions of nanosystems (Maeva, Yakovlev, Pervushin, Buryanov, \& Pustovgar, 2009). The results of the study of physical and technical characteristics, man-made graphite being added, showed that the optimal amount of the added modifier is $0.05 \%$; the compressive and the bending strength of the modified cement binder increased by $10-15 \%$ and $30-35 \%$, respectively.

\section{Conclusions}

Thus, this article presents the study on modification of hydraulic hardening binders with a spectrum of additives alternative to synthesized carbon nanosystems. The results of the study show the positive dynamics of the effect of modifying additives (chrysotile-asbestos nanotubes, carbon black, and graphite) on the strength characteristics. The analysis of the microstructure proves the initiating role of nanodispersed additives, which is manifested in providing conditions for the formation of the crystal-chemical structure of materials.

Changes in the structure formation conditions are also confirmed by typical shifts of absorption lines in the IR spectra of the modified samples. The nature of these changes indicates that nanoscale formations directly affect the nature of the binder hydration. 
The presented results show the possibility of using natural and man-made nanostructured additives instead of synthesized carbon nanosystems without compromising their effectiveness.

\section{Acknowledgement}

Financial supports from the Kalashnikov State University (08.04.01/18PGN) is gratefully acknowledged.

\section{References}

Alafogianni, P., Dassios, K., Tsakiroglou, C. D., Matikas, T. E., \& Barkoula, N. M. (2019). Effect of CNT addition and dispersive agents on the transport properties and microstructure of cement mortars. Construction and Building Materials, 197, 251261. https://doi.org/10.1016/j.conbuildmat.2018.11.169

Asbestos (chrysotile, amosite, crocidolite, tremolite, actinolite, and anthophyllite). (2012). In Arsenic, metals, fibres, and dusts (vol. 100 C. A review of human carcinogens, pp. 219-309). IARC Monographs.

Chuah, S., Pan, Z., Sanjayan, J. G., Wang, Ch. M., \& Duan, W. H. (2014). Nano reinforced cement and concrete composites and new perspective from graphene oxide. Construction and Building Materials, 73, 113-124. https://doi.org/10.1016/j.conbuildmat.2014.09.040

Cwirzen, A., Habermehl-Chirzen, K., \& Penttala, V. (2008). Surface decoration of carbon nanotubes and mechanical properties of cement/carbon nanotube composites. Advances in Cement Research, 20(2), 65-73. https://doi.org/10.1680/adcr.2008.20.2.65

Dillon, F. C., Moghal, J., Koos, A., Lozano, J. G., Miranda, L., Porwal, H., ..., \& Grobert, N. (2015). Ceramic composites from mesoporous silica coated multi-wall carbon nanotubes. Microporous and Mesoporous Materials, 217, 159-166. https://doi.org/10.1016/j.micromeso.2015.06.024

Du, H., Gao, H. J., \& Pang, S. D. (2016). Improvement in concrete resistance against water and chloride ingress by adding graphene nanoplatelet. Cementand Concrete Research, 83, 114-123. https://doi.org/10.1016/j.cemconres.2016.02.005

Fedorova, G. D., Aleksandrov, G. N., Skryabin, A. P., \& Baishev, K. F. (2018). Influence of graphene oxide on the compressive strength of cement stone. Stroitel'nye materialy [Construction Materials], 1-2, 11-17 (in Russian). https://doi.org/10.31659/0585-430X-2018-756-1-2-11-17

Flores Medina, N., \& Barbero-Barrera, M. M. (2017). Mechanical and physical enhancement of gypsum composites through a synergic work of polypropylene fiber and recycled isostatic graphite filler. Construction and Building Materials, 131, 165177. https://doi.org/10.1016/j.conbuildmat.2016.11.073

Flores Medina, N., Barbero-Barrera, M. M., \& Bustamante, R. (2016). Improvement of the properties of gypsum-based composites with recycled isostatic graphite powder from the milling production of molds for Electrical Discharge Machining (EDM) used as a new filler. Construction and Building Materials, 107, 17-27. https://doi.org/10.1016/j.conbuildmat.2015.12.194

Gorshkov, V. S., Saveliev, V. G., \& Abakumov, A. V. (1994). Вяжущие, керамика и стеклокристаллические материаль: Структура и свойства [Astringents, ceramics and glass crystal materials: Structure and properties]. Справочное пособие [The allowance]. Moscow: Stroizdat. $584 \mathrm{c}$.

Hawreen, A., \& Bogas, J. A. (2019). Creep, shrinkage and mechanical properties of concrete reinforced with different types of carbon nanotubes. Construction and Building Materials, 198, 70-81. https://doi.org/10.1016/j.conbuildmat.2018.11.253

Hongyu, Sh., Binmeng, Ch., Bo, L., Shengwen, T., \& Zongjin, L. (2017). Influence of dispersants on the properties of CNTs reinforced cement-based materials. Construction and Building Materials, 131, 186-194. https://doi.org/10.1016/j.conbuildmat.2016.11.053

Yakovlev, G. I., Pervushin, G. N., Pudov, I. A., Dulesova, I. G., Buryanov, A. F., \& Saber, M. (2011). Структуризация цементных вяжущих матриц многослойными углеродными нанотрубками [Structuring cement astringent matrix with multi-layered carbon nanotubes]. Строительные материальь [Building Materials], 11, 22-24.

Kaushansky, V. Е. (1977). Некоторые закономерности гидратационной активности силикатов кальция [Some patterns of hydration activity of calcium silicates]. Журнал прикладной химии [Journal of Applied Chemistry], 8, 1688-1692.

Kharitonov, A., Korobkova, M., \& Smirnova, O. (2015). The influence of low-hard dispersed additives on impact strength of concrete. Procedia Engineering, 108, 239-244. https://doi.org/10.1016/j.proeng.2015.06.143

Kondakov, A. I., \& Mikhaleva, Z. А. (2014). Модификация строительных композитов функционализированным графеном [Modification of construction composites with functionalized graphene]. In Сборник тезисов конференции «Функииональные материаль: разработка, исследование, применение» [A collection of the conference's talking points "Functional materials: development, research, application"]. Tomsk, Tambov. c. 12.

Korayem, A. H., Tourani, N., Zakertabrizi, M., Sabziparvar, A. M., \& Duan, W. H. (2017). A review of dispersion of nanoparticles in cementitious matrices: Nanoparticle geometry perspective. Construction and Building Materials, 153, 346357. https://doi.org/10.1016/j.conbuildmat.2017.06.164

Lin, Ch., Wei, W., \& Hu, Y. H. (2016). Catalytic behavior of graphene oxide for cement hydration process. Journal of Physics and Chemistry of Solids, 89, 128-133. https://doi.org/10.1016/j.jpcs.2015.11.002

Liu, H., Yu, Y., Liu, H., Jin, J., \& Liu, S. (2018). Hybrid effects of nano-silica and graphene oxide on mechanical properties and hydration products of oil well cement. Construction and Building Materials, 191, 311-319. https://doi.org/10.1016/j.conbuildmat.2018.10.029 
Polyanskikh, I.; Yakovlev, G.; Pervushin, G.; Gumeniuk, A.; Gordina, A.; Ignateva, A. 2019.

Structure formation of construction materials modified with natural and man-made nanoadditives

Liu, Y., Han, J., Li, M., \& Yan, P. (2018). Effect of a nanoscale viscosity modifier on rheological properties of cement pastes and mechanical properties of mortars. Construction and Building Materials, 190, 255-264. https://doi.org/10.1016/j.conbuildmat.2018.09.110

Maeva, I. S., Yakovlev, G. I., Pervushin, G. N., Buryanov, A. F., \& Pustovgar, А. Р. (2009). Структурирование ангидритовойматрицы нанодисперсными модифицирующими добавками [Structuring anhydrionic matrix with nanodispersive modification additives]. Строительные материальь [Building materials], 6, 4-5.

Muhd Norhasri, M. S., Hamidah, M. S., \& Mohd Fadzil, A. (2017). Applications of using nano material in concrete: A review. Construction and Building Materials, 133, 91-97. https://doi.org/10.1016/j.conbuildmat.2016.12.005

Peredelsky, L. V., \& Prikhodchenko, O. Е. (2003). Строительная экология [Construction ecology]. Rostov n/D: Phoenix. 320 c.

Pinto, D., Bernardo, L., Amaro, A., \& Lopes, S. (2015). Mechanical properties of epoxy nanocomposites using titanium dioxide as reinforcement - A review. Construction and Building Materials, 95, 506-524. https://doi.org/10.1016/j.conbuildmat.2015.07.124

Reches, Y. (2018). Nanoparticles as concrete additives: Review and perspectives. Construction and Building Materials, 175, 483495. https://doi.org/10.1016/j.conbuildmat.2018.04.214

Santagata, E., Baglieri, O., Tsantilis, L., \& Chiappinelli, G. (2013). Effects of nano-sized additives on the high-temperature properties of bituminous binders: A comparative study. In N. Kringos, B. Birgisson, D. Frost, \& L. Wang (Eds.), Multi-scale modeling and characterization of infrastructure materials (RILEM Bookseries, vol. 8). Springer, Dordrecht. https://doi.org/10.1007/978-94-007-6878-9_22

Sarajkina, K. A., Golubev, V. A., Yakovlev, G. I., Fedorova, G. D., Aleksandrov, G. N., Plekhanova, T. A., \& Dulesova, I. G. (2015). Modification of basalt fiber concrete by nanodispersed systems. Stroitel'nye materialy, 10, 64-69 (in Russian).

Shang, Y., Zhang, D., Yang, Ch., Liu, Y., \& Liu, Y. (2015). Effect of graphene oxide on the rheological properties of cement pastes. Construction and Building Materials, 96, 20-28. https://doi.org/10.1016/j.conbuildmat.2015.07.181

Singh, L. P., Bhattacharyya, S. K., Shah, S. P., Mishra, G., \& Sharma, U. (2016). Studies on early stage hydration of tricalcium silicate incorporating silica nanoparticles: Part II. Construction and Building Materials, 102, Part 1, 943-949. https://doi.org/10.1016/j.conbuildmat.2015.05.084

Trineeva, V. V. (2009). Разработка и исследование механохимического способа получения углеродных металлсодержащих наноструктур [Development and research of a mechanochemical method of obtaining carbon-containing nanostructures] (autoref.). 05.16.06. M.

Voitovich, E., Cherevatova, A., Zhernovsky, I., Fisher, H., \& Sobolev, K. (2014). The application of nano-structured silica based admixture in gypsum binders. MRS Proceedings, 1611, 165-170. https://doi.org/10.1557/opl.2014.774 